[Agr. Biol. Chem., Vol. 31, No. 6, p. 694 699, 1967]

\title{
Studies on Biosynthesis of Biotin by Microorganisms
}

\author{
Part VII. Some Properties of Avidin-uncombinable \\ Biotin-Vitamer Produced by Bacillus sp.
}

\author{
By Shojiro Iwahara*, Masakazu KikuchI, Tasurokuro Tochrkura \\ and Koichi OGata \\ Department of Agricultural Chemistry, Faculty of Agriculture, \\ Kyoto University, Kyoto \\ Received January 18, 1967
}

\begin{abstract}
A biotinless mutant (K-681-UV-134) accumulated a large amount of desthiobiotin and an unknown biotin-vitamer in the culture medium.

The parent strain (K-681) of this mutant isolated from soil was identified as Bacillus cereus.

The unknown vitamer was accumulated at the early stage of the incubation in comparison with desthiobiotin.

The unknown vitamer was purified by the paper- and column-chromatographic methods from the culture filtrate. The purified vitamer gave a single spot when spraying with the ninhydrin reagent after paper chromatographing and its $R_{F}$ values in several solvent systems were identical with those of authentic 7-keto-8-aminopelargonic acid.
\end{abstract}

\section{INTRODUCTION}

In the previous papers of this series, ${ }^{1,2}$ the authors reported that, in addition to a large amount of desthiobiotin, an unknown vitamer was accumulated by various bacteria. This unknown vitamer was proved to be avidinuncombinable and was assumed to be an analogue of pelargonic acid from the results of ion-exchange column chromatographic and paper electrophoretic studies.

Among the recent reports about biotinvitamers, Eisenberg ${ }^{31}$ demonstrated that Phycomyces blakesleeanus accumulated, in the culture medium, desthiobiotin, biotin, bio-

* Present address: Department of Agricultural Chemistry, Faculty of Agriculture, Kagawa University, Miki-cho, Kagawa-ken, Japan.

1) K. Ogata, T. Tochikura, S. Iwahara, S. Takasawa, K. Ikushima, A. Nishimura and M. Kikuchi, This Journal, 29, 889 (1965).

2) K. Ogata, T. Tochikura, S. Iwahara, K. Ikushima, S. Takasawa, A. Nishimura and M. Kikuchi, ibid., 29, 895 (1965).

3) M. A. Eisenberg, J. Bacteriol., 86, 673 (1963). cytin, biotin- $d$-sulfoxide and an avidin-uncombinable unknown biotin-vitamer. Dhyse and Hertz $^{4}$, Genghof ${ }^{5 !}$ and Rose et al. ${ }^{6}$ also demonstrated the existence of the similar avidinuncombinable compound in the culture media of Escherichia coli, Corynebacterium xerosis and Pseudnmonas sp. respectively.

More recently, Eisenberg ${ }^{71}$ demonstrated that the unknown vitamer contained no sulphur atom in the molecule. However, these works appear not to provide the sufficient properties of the unknown vitamer.

The present investigation was undertaken to clarify further the characteristics of the unknown vitamer and to identify the bacteria which accumulated much amount of the un-

4) F.G. Dhyse and R. Hertz, Arch. Biochem. Biophys., 74, 7 (1958)

5) D.S. Genghof, Arch. Biochem. Biophys., 62, 63 (1956).

6) A.H. Rose, M. Ilahi and M. V. Kelemen, Biochem. J., 96, 319 (1966).

7) M. A. Eisenberg, Biochem. J., 98, 15c (1966). 
known vitamer in the culture medium. The results showed that the unknown vitamer might be 7-keto-8-aminopelargonic acid and the bacterium (K-681) which was the parent strain of biotinless mutant (K-681-UV-134) was identified as Bacillus cereus by taxonomic studies.

\section{MATERIALS AND METHODS}

Microorganism. Biotinless mutant, parent strain of which was isolated from soil, was mainly subjected to this investigation.

Determination of Microorganism. The identification of microorganism isolated form soil was carried out according to the description in Bergey's Manual of Determinative Bacteriology, 7 th ed. ${ }^{8}$ )

Ultraviolet Light Irradiation and Characterization of Biochemical Mutant. Irradiation of bacteria on the nutrient agar was given by one or two minute exposure to Toshiba Sterile Lamp $(0.9 \mathrm{~W}$, $0.3 \mathrm{~A})$ at a distance of $25 \mathrm{~cm}$ with a modification of the method of Lederberg ${ }^{91}$. To determine the nutritional requirements, the auxanographic method ${ }^{10}$, was adopted.

Media and Cultivation.

1) The medium for irradiation: peptone, $10 \mathrm{~g}$; meat extract, $10 \mathrm{~g}$; yeast extract, $1 \mathrm{~g}$; glycerin, $20 \mathrm{~g}$; $\mathrm{K}_{2} \mathrm{HPO}_{4}, 0.5 \mathrm{~g} ; \mathrm{KH}_{2} \mathrm{PO}_{4}, 0.5 \mathrm{~g} ; \mathrm{KCl}, 0.5 \mathrm{~g} ; \mathrm{MgSO}_{4}$. $7 \mathrm{H}_{2} \mathrm{O}, 0.5 \mathrm{~g}$; agar, $20 \mathrm{~g}$; in $1000 \mathrm{ml}$ of tap water. The $\mathrm{pH}$ was adjusted to 7.2 .

2) The medium for cultivation: $\mathrm{NH}_{4} \mathrm{Cl}, 10 \mathrm{~g}$; $\mathrm{DL}$ alanine, $10 \mathrm{~g} ;$ glucose, $20 \mathrm{~g} ; \mathrm{K}_{2} \mathrm{HPO}_{4}, 0.5 \mathrm{~g} ; \mathrm{KCl}$, $0.5 \mathrm{~g} ; \quad \mathrm{MgSO}_{4} \cdot 7 \mathrm{H}_{2} \mathrm{O}, 0.5 \mathrm{~g} ; \quad \mathrm{NaHCO}_{3}, \quad \mathrm{~g}$; yeast extract, $1 \mathrm{~g}$; pimelic acid, $1 \mathrm{~g}$; trace element solution ${ }^{11}, 1 \mathrm{ml}$ in $1000 \mathrm{ml}$ of tap water. The initial $\mathrm{pH}$ was 7.2 .

3) The minimum medium for auxanographic method: $\mathrm{NH}_{4} \mathrm{Cl}, 10 \mathrm{~g}$; glycerol, $20 \mathrm{~g} ; \mathrm{K}_{2} \mathrm{HPO}_{4}, 0.5 \mathrm{~g}$; $\mathrm{KCl}, 0.5 \mathrm{~g}, \mathrm{NaHCO}_{3}, \mathrm{I} \mathrm{g} ; \mathrm{MgSO}_{4} \cdot 7 \mathrm{H}_{2} \mathrm{O} 0.5 \mathrm{~g}$ trace element solution ${ }^{11)}, \mathrm{I} \mathrm{ml}$ in $1000 \mathrm{ml}$ of deionized water.

Cultivation.

To determine the producibility of biotin-vitamers by the microorganism, $4 \mathrm{ml}$ of the medium in a test

8) R. S. Breed, E. G. D. Murray and N. R. Smith, "Bergey's Manual of Determinative Bacterialogy," 7th ed., Williams \& Wilkins Co., 1957, p. 613.

9) J. Lederberg, J. Bacteriol., 52, 503 (1946).

10) R. W. Gerard et al., "Methods in Medical Research", Vol. 3, The Year Book Publishers, 1950, p. 15 .

11) P. R. Burkholder and D. Moyer, Bull. Torrey Bot. Club, 70, 372 (1943). tube $(16 \mathrm{~mm} \times 180 \mathrm{~mm})$ was incubated for 2 days at $28^{\circ} \mathrm{C}$ with continuous shaking (280 reciprocations per minute). The content of biotin-vitamers in the broth was determined.

For the preparation of the unknown vitamer, the preincubated biotinless mutant (K-682-UV-134) in $4 \mathrm{ml}$ of the medium was inoculated into $400 \mathrm{ml}$ of the medium in $2000-\mathrm{ml}$ shaking flask, and incubated for 3 days at $28^{\circ} \mathrm{C}$ on a shaker (140 recpirocations per minute).

\section{Determination of Biotin-Vitamers.}

Biotin-vitamers were quantitatively determined by microbiological assay according to the general assay method of Snell et al.12)

A short ion-exchange column $(16 \mathrm{~mm} \times 30 \mathrm{~mm})$ of Dowex- $1 \times 2$ (formate) was employed for fractional determination of desthiobiotin and the unknown vitamer. After $\mathrm{pH}$ of the culture filtrate cantaining the unknown vitamer and desthiobiotin was adjusted to about $6,0.1$ to $1 \mathrm{ml}$ of the filtrate was placed on the column, the unknown vitamer was washed out with 50 to $100 \mathrm{ml}$ of deionized water, and then desthiobiotin was eluted with $20 \mathrm{ml}$ of $0.1 \mathrm{M}$ fomic acid. Desthiobiotin and unknown vitamer in each fraction were quantitatively determined by the microbiological assay with Saccharomyces cerevisiae according to the method described above.

\section{Paper Chromatography.}

Ascending paper chromatography was carried out on Tôyô Roshi No. 53 filter paper with the following solvent systems; pyridine-water $(7: 3, \mathrm{v} / \mathrm{v}), n$-butanolformic acid-water $(4: 1: 1, \mathrm{v} / \mathrm{v} / \mathrm{v}), n$-butanol-acetic acidwater $(12: 3: 5, v / v / v), n$-butanol-I $\mathrm{N}$ hydrochloric acid $(6: 1, v / v)$. The bioautographic technique was used to detect the vitamers on the paper chromatograms with Saccharomyces cerevisiae according to the method reported in the previous paper. $\left.{ }^{2}\right)$ Ninhydrin reagent was also used to visualize the unknown vitamer on the paper chromatograms.

\section{RESULTS AND DISCUSSION}

Taxonomic Studies of Isolated Bacteria.

The provious paper ${ }^{2}$ indicated that various bacteria accumulated desthiobiotin and an unknown biotin-vitamer in the culture media. According to the results of screening tests, isolated bacteria which were capable of

12) E. E. Snell, R. E. Eakin and R.J. Williams, J. Am. Chem. Soc., 62, 175 (1940). 
accumulating the unknown vitamer seemed to belong mostly to genus Bacillus. Among these bacteria, K-681, from which biotinless mutant was obtained, was subjected to this experiments.

The results of taxonomic studies are shown in Table I and Fig. 1(A and B). In general, the microorganism was rods with square ends, occurred in chain and spores were ellipsoidal (Fig. 1(B)). The organism was motile with flagella (Fig. 1(A)), gram-positive, growing well aerobically forming a soft pellicle, and had favorable $\mathrm{pH}$ of 7 to 8 .

Almost all the characteristics of this strain were exactly the same to both Bacillus subtilis and Bacillus cereus. Although Bacillus cereus is

\section{TABLE I. Characteristics OF} ISOLATED BACTERIA.

Morphological

Rods, 0.8 to 1.2 by 1.6 to $3.6 \mu$ with square ends, occurring in chain. Gram-positive. Motile.

Spores, 0.6 to 1.0 by 1.2 to $2.5 \mu$, ellipsoidal.

Sporangia not definitely swollen.

Cultural

(1) Nutrient agar colony: Large, flat and undulate.

(2) Nutrient agar slant: Growth abundant, rough, whitish, edge irregular with whip-like outgrowths.

(3) Nutrient agar stab: Best growth on the top, beaded.

(4) Nutrient broth: Forming a soft pellicle.

Physiological.

( 1 ) $\mathrm{pH}$ : Optimum 7 to 8 , range 5 to 9 .

(2) Heat tolerant.

(3) Aerobic.

(4) Gelatin: Rapid liquefaction.

(5) Litmus milk: No acid.

(6) Milk: Slight peptonization with slight coagulation.

(7) Indole not produced.

(8) Starch hydrolyzed.

(9) Acetylmethylcarbinol produced.

(10) Catalase positive.

(11) Nitrites produced from nitrates.

(12) Methyl red test: Negative.

(13) Acid but no gas from glucose, fructose, sucrose, maltose, glycerin and starch.

(14) Source: Isolated from soil.

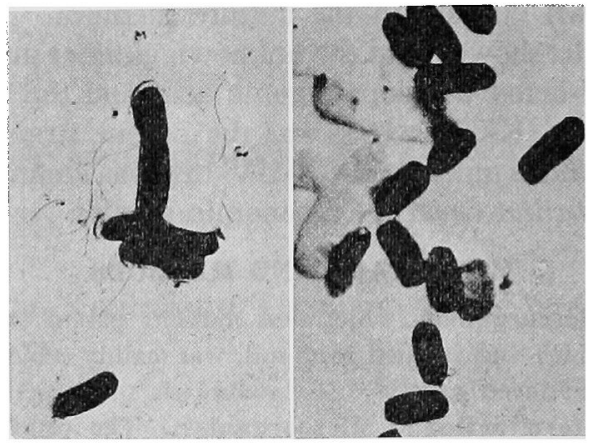

(A)

(B)

FIG. 1. Electron Micrographs of Strain K-681 (magnification, $\times 33,000$ ).

(A): Vegetative Cell, (B): Spore.

sometimes confused with Bacillus subtilis according to the descriptions in Bergey's Manual, it is possible to differentiate between the two strains by the ability to ferment sugars.

Bergey's Manual demonstrated that Bacillus subtilis produces acid but no gas from glucose,

TABLE II. IMPROVEMENT OF STRAIN K-681 Biotin-vitamers accumulated ( $\mu \mathrm{g}$ per $\mathrm{ml}$ ) Precursor

Strain Method**

Pimelic acid Azelaic acid $\overbrace{\begin{array}{r}\text { Total } \\ \text { biotin }\end{array}}^{\mathrm{UNBV}^{*} *} \overbrace{\begin{array}{r}\text { Total } \\ \text { biotin }\end{array}}^{\mathrm{UNBV}^{*}}$

A(K-681)

$2.8 \quad 1.0$

$\stackrel{\downarrow}{\mathrm{B}} \quad \mathrm{S}$

$\downarrow$

$\downarrow$

$\downarrow$

$\downarrow$

F $\quad$ UV, S

$\downarrow \quad \downarrow \quad$ UV

$\downarrow \quad \downarrow \quad$ UV

$3.6 \quad 1.2$

0.6

2.4

$\downarrow$

5.0

7.0

15.0

(K-681-UV-134)

$60.0 \quad 15.0$

20.0

10.0

* Unknown vitamer,

** S: Single-cell culture, UV: UV-irradiation.

cf. During this improvement of this strain, azelaic acid was mainly employed as the precursor. 
xylose, arabinose and mannitol. However, the test organism produced acid from glucose, fructose, sucrose, maltose, glycerol and starch, but not from xylose, arabinose and mannitol. These properties were identical with those of Bacillus cereus. From the results, it would be appropriate to conclude that the test organism is Bacillus cereus.

\section{Improvement of Strain K-681.}

To enhance the ability of strain K-681 to accumulate biotin-vitamers, UV-irradiation and single cell culture were carried out several times. The results are summarized in Table II. The procedures made enhancement of the ability to accumulate total biotin-vitamers and the unknown vitamer about 20-fold respectively. Moreover, the mutant (K-681-UV-134) which was the best producer of the unknown vitamer was found to require biotin for its growth.

Effect of Nitrogen Source on Bacterial Growth and on Accumulation of Biotin-Vitamers.

Organic nitrogen sources are effective on bacterial growth and on the accumulation of biotin-vitamers, but much difficulties arise in purifying the unknown vitamer from the culture medium. In the present study, various nitrogen sources were tested to employ synthetic or semisynthetic medium.

The minimal medium, from which ammonium chloride was removed and to which pimelic acid was supplemented, was adopted in this experiment. Nitrogen sources were added to this minimal medium to be 2 per cent.

The results in Table III show that inorganic nitrogen sources such as ammonium chloride, ammonium sulfate and sodium nitrate were relatively effective with the addition of yeast extract. Using these nitrogen sources, about $2 \mu \mathrm{g}$ per $\mathrm{ml}$ of total biotin was accumulated, but there was much decrease in the production of biotin-vitamers as compared with the case of the medium cantaining organic nitrogen sources. Casamino acids and amino acids had no effect without the addition of yeast extract.
TABLE III. EFFECT OF NITROGEN SOURCES.

The bacterium was grown for 2 days at $28^{\circ} \mathrm{C}$ on a shaker (280 reciprocations per minute) $\begin{array}{cc}\text { Nitrogen source } & \text { Yeast ext. } \\ (2 \%) & (0.1 \%)\end{array}$ Growth* $\begin{gathered}\text { Total biotin** } \\ \text { accumulated } \\ (\mu \mathrm{g} \text { per ml) }\end{gathered}$

\begin{tabular}{|c|c|c|c|}
\hline Peptone & $\left\{\begin{array}{l}+ \\
-\end{array}\right.$ & $\begin{array}{l}7.20 \\
7.30\end{array}$ & $\begin{array}{l}20.0 \\
20.1\end{array}$ \\
\hline Casamino acid & $\left\{\begin{array}{l}+ \\
-\end{array}\right.$ & $\begin{array}{l}2.20 \\
0.65\end{array}$ & $\begin{array}{r}11.1 \\
1.0\end{array}$ \\
\hline $\mathrm{NH}_{4} \mathrm{Cl}$ & $\left\{\begin{array}{l}+ \\
-\end{array}\right.$ & $\begin{array}{l}1.15 \\
0.05\end{array}$ & $\begin{array}{l}2.0 \\
0.0\end{array}$ \\
\hline $\mathrm{CO}\left(\mathrm{NH}_{2}\right)_{2}$ & $\left\{\begin{array}{l}+ \\
-\end{array}\right.$ & $\begin{array}{l}0.30 \\
0.00\end{array}$ & $\begin{array}{l}0.0 \\
0.0\end{array}$ \\
\hline$\left(\mathrm{NH}_{4}\right)_{2} \mathrm{SO}_{4}$ & $\left\{\begin{array}{l}+ \\
-\end{array}\right.$ & $\begin{array}{l}1.15 \\
0.09\end{array}$ & $\begin{array}{l}2.4 \\
0.0\end{array}$ \\
\hline$\left(\mathrm{NH}_{4}\right)_{2} \mathrm{HPO}_{4}$ & $\left\{\begin{array}{l}+ \\
-\end{array}\right.$ & $\begin{array}{l}1.05 \\
0.00\end{array}$ & $\begin{array}{l}0.6 \\
0.0\end{array}$ \\
\hline$\left(\mathrm{NH}_{4}\right) \mathrm{H}_{2} \mathrm{PO}_{4}$ & $\left\{\begin{array}{l}+ \\
-\end{array}\right.$ & $\begin{array}{l}1.60 \\
0.15\end{array}$ & $\begin{array}{l}0.9 \\
0.0\end{array}$ \\
\hline $\mathrm{NaNO}_{3}$ & $\left\{\begin{array}{l}+ \\
-\end{array}\right.$ & $\begin{array}{l}2.00 \\
0.15\end{array}$ & $\begin{array}{l}2.4 \\
0.0\end{array}$ \\
\hline $\mathrm{NH}_{4}$-Tartarate & $\left\{\begin{array}{l}+ \\
-\end{array}\right.$ & $\begin{array}{l}0.90 \\
0.00\end{array}$ & $\begin{array}{l}0.0 \\
0.0\end{array}$ \\
\hline $\mathrm{Na}$-Aspartate & $\left\{\begin{array}{l}+ \\
-\end{array}\right.$ & $\begin{array}{l}2.35 \\
0.40\end{array}$ & $\begin{array}{l}7.0 \\
0.0\end{array}$ \\
\hline $\mathrm{Na}$-Glutamate & $\left\{\begin{array}{l}+ \\
-\end{array}\right.$ & $\begin{array}{l}2.60 \\
0.45\end{array}$ & $\begin{array}{l}4.0 \\
0.0\end{array}$ \\
\hline
\end{tabular}

* Optical density at $610 \mathrm{~m} \mu$.

** Assayed with Saccharomyces cerevisiae.

The various attempts following this study led to the conclusion that combination of $1 \%$ of ammonium chloride and $1 \%$ of DL-alanine as nitrogen sources and $0.1 \%$ of yeast extract as growth factor is most effective as the cultural condition. Using this medium, almost the same amounts ( 15 to $20 \mu \mathrm{g}$ per ml) of total biotin-vitamer as that using organic medium (peptone) were accumulated.

Time Course of Accumulation of BiotinVitamers.

As shown in Fig. 2, it was found that the amounts of total biotin produced in the culture medium reached a maximum just after the maximum growth of the microorganism. On the other hand, the unknown vitamer is accumulated in higher yields than desthiobiotin within three days and then decreases gradually. This fact leads to the supposition that the unknown vitamer might 


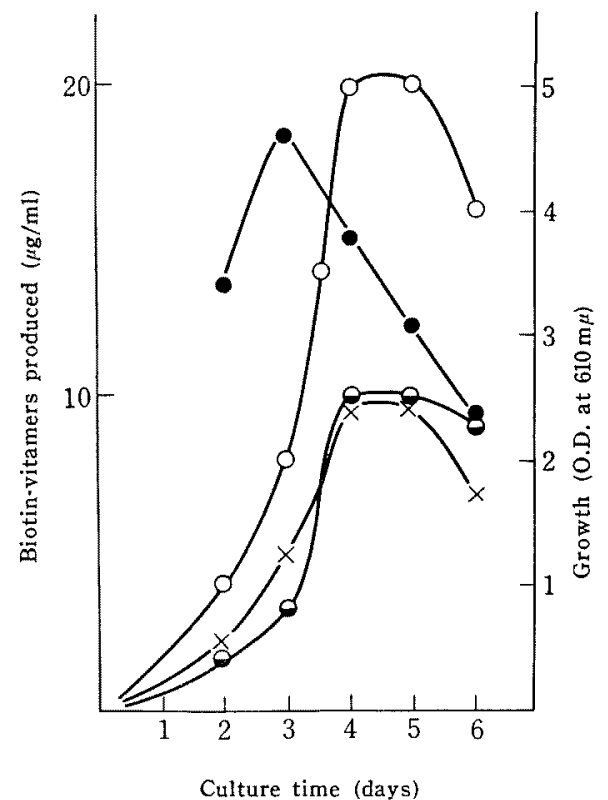

FIG. 2. Time Course of Accumulation of BiotinVitamers.

$-\mathrm{O}$ : total biotin, $-\times-$ : $\begin{aligned} & \text { unknown biotin- } \\ & \text { vitamer. }\end{aligned}$
- - : desthiobiotin, - - - growth.

be produced in the earlier stage of the incubation and be gradually converted to desthiobiotin.

\section{Purification of the Unknown Vitamer.}

Although the brief method to purify the unknown vitamer was reported in the previous paper, ${ }^{2 \prime}$ in the present study the partial improvement was made to reduce the loss of the vitamer during the purification and to obtain more purified sample as follows.

The excess of lead acetate was added to broth and centrifuged. Sulfuric acid was added to the supernatant to remove the lead ion. Phosphotungstic acid was added to the supernatant and the precipitates formed were removed by centrifugation. Then the supernatant was adjusted to the $\mathrm{pH} 3$ and mixed with 2 per cent of charcoal overnight with stirring occasionally. The charcoal was filtrated and eluted with twenty times of its quantity of 80 per cent ethanol with continuous stirring for 2 hours. The charcoal treatment was repeated and the combined eluate was concentrated in vacuo to syrup and the vitamer was extracted with 90 per cent ethanol. This extract was concentrated again and adjusted to the $\mathrm{pH} 5$ to 6 . This concentrate (obtained from about 10 liters of the culture medium) was then placed onto Dowex-1 $\times 2$ (formate) column $(30 \mathrm{~mm} \times 400$ $\mathrm{mm})$. The unknown vitamer was washed out with deionized water, then the washings were concentrated again and, after adjusting the $\mathrm{pH}$ to 5 to 6 , were placed onto Dowex- 50 $\mathrm{W}\left(\mathrm{H}^{+}\right)$column $(30 \mathrm{~mm} \times 500 \mathrm{~mm})$. The column was washed with deionized water to remove the unadsorbed contaminants. The unknown vitamer was eluted from the column with $2 \mathrm{~m}$ hydrochloric acid. The fractions having biotin activity were pooled and concentrated to dryness in vacuo at room temperature. The dried materials were dissolved in about $20 \mathrm{ml}$ of 90 per cent ethanol. This solution was further treated by ascending paper chromatography on large sheets of Tôyô Roshi No. 53 filter paper with several solvent systems. The area showing biotin activity were cut out and eluted with 50 per cent ethanol. The eluate was concentrated to about $20 \mathrm{ml}$ in vacuo. This paper chromatographic treatment was repeated several times until other vitamers were not observed. This concentrated solution was subjected to the following experiments. From about 100 liters of the broth, about $40 \mathrm{mg}$ of the unknown vitamer (as biotin activity) as the concentrated solution could be obtained.

Paper Chromatographic Properties of the Unknown Vitamer

The general properties, that is, biological activity, paper electrophoretic mobilities and affinity for avidin of the vitamer, were the same as those described in the previous paper $^{21}$. In the present study, in order to 


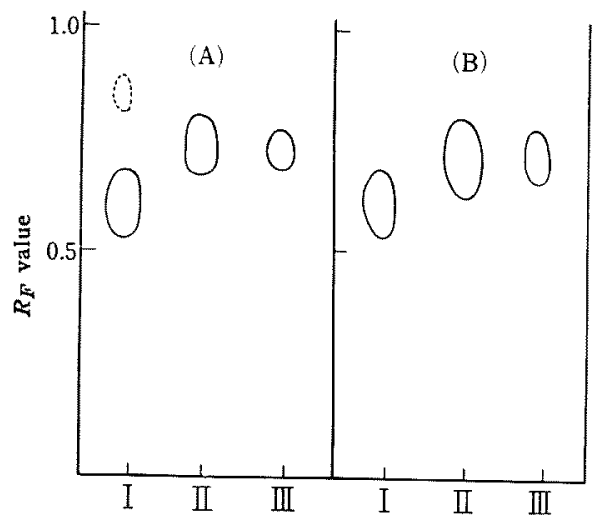

FIG. 3. Paper Chromatograms of the Unknown Biotin-Vitamer.

I: 7-Amino-8-keto-pelargonic acid, II: 7-Keto-8amino-pelargonic acid, III: Unknown vitamer

(A): Detected with ninhydrin reagent

(B): Detected with Saccharomyces cerevisiae

Solvent system: Pridine-water (7:3).

further clarify the characteristics of the vitamer, paper chromatographic properties of the unknown vitamer were investigated.

As will be seen from the results of Fig. 3, the vitamer was ninhydrin positive, and the position of the ninhydrin-positive spots on the paper chromatograms in several solvent systems were quite similar with those of bioautographic results. Other ninhydrin-positive substances were not observed on the paper chromatograms in all solvent systems tested. This fact suggests the existence of amino radical in the molecule of the vitamer. Moreover, as shown in Table IV, the $R_{F}$

TABLE IV, $R_{F}$ VALUES OF BIOTIN-VITAMERS

Material

Unknown vitamer isolated

7-Keto-8-amino-pelargonic acid

7-Amino-8-keto-pelargonic acid

7, 8-Diamino-pelargonic acid

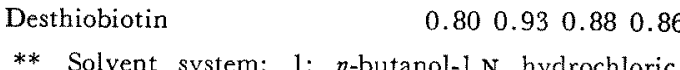
acid (6:1).

2: pyridine-water $(7: 3)$.

3: $n$-butanol-acetic acid-water (12:3:5).

4: $n$-butanol-formic acid-water $(4: 1: 1)$.

* Detected with Sacchromyces cerevisiae. The $R_{F}$ values detected with ninhydrin reagent were the same as those detected with Saccharomyces cerevisiae.

values of the vitamer were identical with those of authentic 7-keto-8-amino-pelargonic acid. From these results, the posibility might exist that the unknown vitamer seems not to be 7-amino-8-keto-pelargonic acid, but to be 7-keto-8-amino-pelargonic acid.

The detailed chemical characteristics of the vitamer are under investigation.

Acnowledgement The authors are indebted to Ajinomoto Co., Inc., for the generous gifts of 7-keto-8-amino-pelargonic acid, 7amino-8-keto-pelargonic acid and 7,8-diaminopelargonic acid. They also wish to thank Dr. H. Yamada, Assistant Professor, Institute for Food Science of Kyoto University, for many helpful advices during this work. 